THE DANCING LARES AND

THE SERPENT IN THE GARDEN 



\section{THE DANCING LARES}

AND THE SERPENT

\section{IN THE GARDEN}

Religion at the Roman Street Corner

Harriet I. Flower 
Copyright @ 2017 by Princeton University Press

Published by Princeton University Press,

41 William Street, Princeton, New Jersey 08540

In the United Kingdom: Princeton University Press, 6 Oxford Street, Woodstock, Oxfordshire OX20 1TR

press.princeton.edu

Jacket art: Lares and Genius. Fresco. Imperial Roman, 69-79 CE. From a lararium in Pompeii. In the lower part are two snakes crawling towards a cista mystica (sacred chest, or basket, used to house snakes). Museo Archeologico Nazionale, Naples, Italy. ( ) Vanni Archive / Art Resource, NY.

All Rights Reserved

Library of Congress Cataloging-in-Publication Data

Names: Flower, Harriet I., author.

Title: The dancing lares and the serpent in the garden : religion at the Roman street corner / Harriet I. Flower.

Description: Princeton : Princeton University, 2017. | Includes bibliographical references and index.

Identifiers: LCCN 2016055317 | ISBN 9780691175003 (hardcopy : alk. paper)

Subjects: LCSH: Lares. | Serpents-Religious aspects. | Cults-Rome. | Rome-Religious life and customs. | Rome-Religion.

Classification: LCC BL820.L3 F59 2017 | DDC 292.07-dc23 LC record available at https://lccn.loc.gov/2016055317

British Library Cataloging-in-Publication Data is available

This publication is made possible in part from the Barr Ferree Foundation Fund for Publications, Department of Art and Archaeology, Princeton University

This book has been composed in Adobe Text Pro

Printed on acid-free paper. $\infty$

Printed in the United States of America

$\begin{array}{llllllllll}10 & 9 & 8 & 7 & 6 & 5 & 4 & 3 & 2 & 1\end{array}$ 
This book is dedicated to the memory of Robert E. A. Palmer

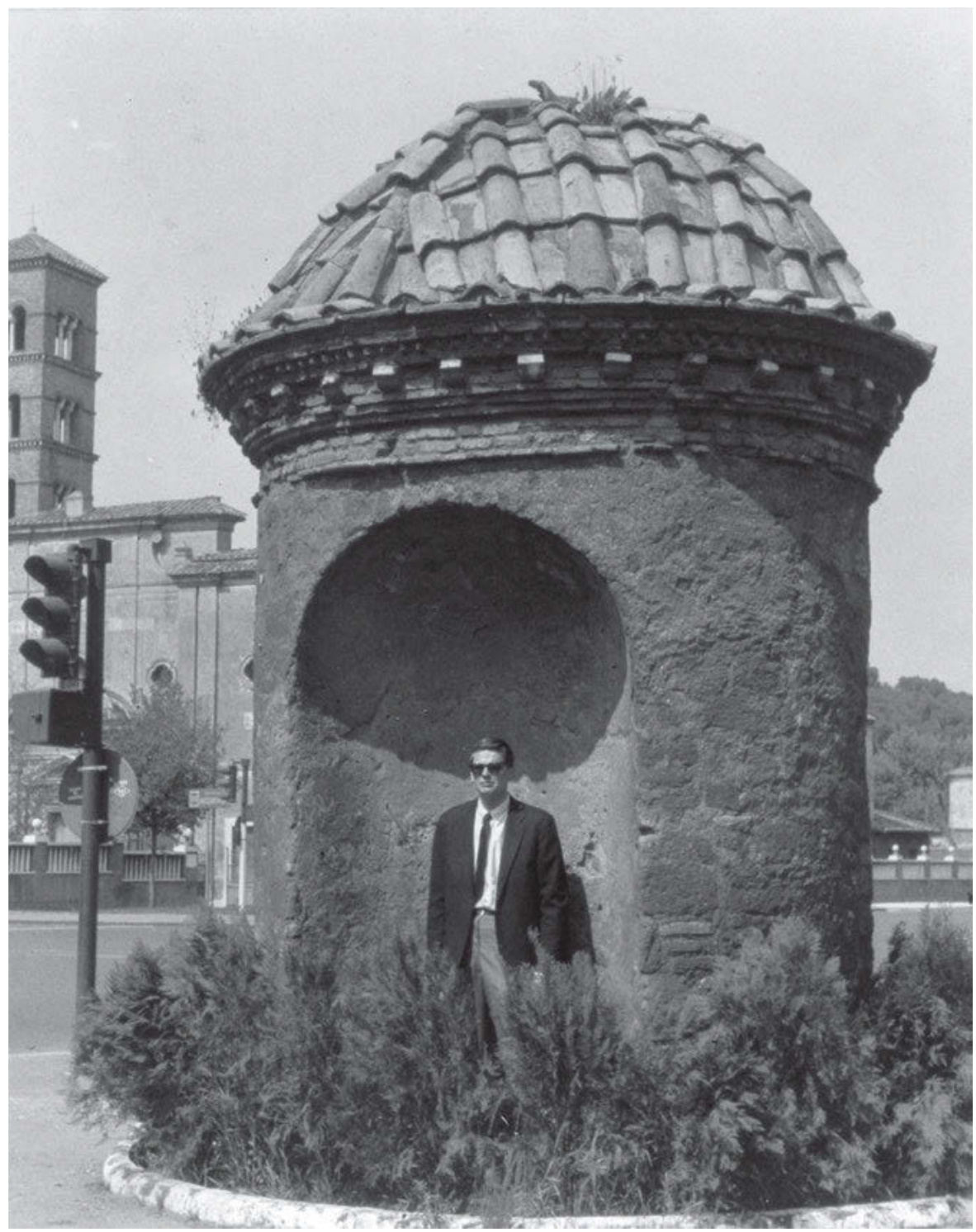

Frontispiece. Robert E. A. Palmer in front of a compitum (a small, round structure of uncertain age) at the Piazza di Numa Pompilio, Rome, where the Via Appia and Via Latina meet two vici Sulpicii. Bell tower of San Sisto Vecchio in the background. 
